\title{
Agronomic and Economic Evaluation of Hydrogel Application in Rainfed Castor Grown on Alfisols
}

\author{
A.V. Ramanjaneyulu ${ }^{1 *}$, A. Madhavi ${ }^{2}$, G. Anuradha ${ }^{1}$, M. Venkata Ramana ${ }^{1}$, \\ G. Suresh ${ }^{3}$, B. Balaji Naik ${ }^{4}$ and G. Seshu ${ }^{1}$
}

${ }^{1}$ Regional Agricultural Research Station, Palem 509 215, India

${ }^{2}$ Soil Test Crop Response Scheme, ${ }^{4}$ Agro Climate Research Center, Rajendranagar 500030 , Professor Jayashankar Telangana State Agricultural University, Telangana state, India ${ }^{3}$ ICAR-Indian Institute of Oilseeds Research, Rajendranagar 500 030, Hyderabad, India

*Corresponding author

\begin{tabular}{|c|c|c|}
\hline & \multicolumn{2}{|l|}{ A B S T R A C T } \\
\hline $\begin{array}{l}\text { Castor, Drought, } \\
\text { Economic } \\
\text { evaluation, } \\
\text { Hydrogel }\end{array}$ & \multirow{3}{*}{\multicolumn{2}{|c|}{$\begin{array}{l}\text { A field experiment was conducted during kharif } 2016 \text { and } 2017 \text { on Alfisols to test } \\
\text { the impact of hydrogel application on rainfed castor. The study indicated that } \\
\text { despite slight improvement in soil moisture content due to hydrogel amendment, it } \\
\text { failed to bring out significant increase in growth and yield traits thus seed yield of } \\
\text { rainfed castor. Further, net returns and B:C ratio were reduced due to hydrogel } \\
\text { application as compared to control. Additional net returns were also negative (Rs. } \\
-4594 \text { to }-11547 \mathrm{ha}^{-1} \text { ) due to additional cost (Rs. } 3500 \text { to } 10500 \mathrm{ha}^{-1} \text { ) incurred } \\
\text { following hydrogel application. Hence, hydrogel application couldn't show great } \\
\text { impact on rainfed castor productivity due to its' long duration, indeterminate } \\
\text { nature and inherent ability to withstand short term droughts. }\end{array}$}} \\
\hline Article Info & & \\
\hline $\begin{array}{l}\text { Accepted: } \\
\text { 24 June } 2018 \\
\text { Available Online: } \\
\text { 10 July } 2018\end{array}$ & & \\
\hline Introduction & & $\begin{array}{l}\text { India is the global leader with } 66 \% \text { area }(8.23 \\
\text { lakh ha), } 80 \% \text { production ( } 14.21 \text { lakh tonnes) }\end{array}$ \\
\hline \multicolumn{2}{|c|}{$\begin{array}{l}\text { Castor is one of the ancient and important } \\
\text { non-edible oilseeds grown in } 30 \text { countries } \\
\text { across the globe in tropical and subtropical } \\
\text { regions. Castor oil and its' by products have } \\
\text { multifarious uses in agricultural, industrial, } \\
\text { medicinal and ornamental fields } \\
\text { (Ramanjaneyulu et al., 2017). Globally castor } \\
\text { is cultivated in an area of } 12.5 \text { lakh ha with a } \\
\text { production of } 17.7 \text { lakh tonnes and a } \\
\text { productivity of } 1414 \mathrm{~kg} \mathrm{ha}^{-1} \text { (www.fao.org). }\end{array}$} & $\begin{array}{l}\text { and highest productivity (1713 } \mathrm{kg} \mathrm{ha} \mathrm{ha}^{-1} \text { ) in } \\
\text { castor. In India, the crop is grown in more } \\
\text { than } 1.0 \text { lakh ha area purely under rainfed } \\
\text { conditions (IIOR, 2018) characterized by low } \\
\text { and erratic distribution of rainfall leading to } \\
\text { occurrence of mid season or terminal dry spell } \\
\text { finally leading to reduced yields. In view of } \\
\text { global climate change, frequency of dryspells } \\
\text { or drought may still aggravate the problem of } \\
\text { soil moisture availability leading to significant }\end{array}$ \\
\hline
\end{tabular}


reduction in crop yields. Further, castor is raised by resource poor farmers in arid and semiarid regions, mostly on marginal and sub marginal lands having shallow depth, low water holding capacity, less clay and organic matter (Abdelfattah, 2013) besides the problems like vulnerability to soil erosion and poor native fertility (Falkenmark and Rockström, 2004). No doubt, castor being drought hardy plant, is well adapted to low moisture conditions with its deep root system and reflective bloom on stems and leaves to reduce heat load and thrive under conserved moisture. However, yields are greatly reduced under limited moisture supply conditions. Low cost moisture conservation practice such as ridge and furrow has been proved to enhance castor seed yield by $6.5-12 \%$ over dead furrow and flat bed method of land configuration (Krishna and Ramanjaneyulu, 2012). Further, scheduling of life saving irrigation with farm pond water through drip irrigation @ 30 mm resulted in $62 \%$ higher seed yield (Ramanjaneyulu et al., 2015). Though the first method is less costly, yield improvement was marginal. While, in the second method, though yield improvement is substantial, the technology is not affordable by the small and marginal farmers unless creation of infrastructure like drip irrigation material and farm pond are completely supported by the government. Hence, new strategies have to be adopted to mitigate the ill effects of drought. One such novel approach is thought to be use of hydrogels in Agriculture.

Hydrogels are superabsorbent polymers (SAPs) which on an average, hold 332-465 times water of its weight and release it slowly in drought stress conditions in light soils (Dehkordi, 2016). Due to their threedimensional cross linked hydrophilic polymer networks, hydrogels are subjected to swelling and retain large amount of water or deswelling to loose its moisture. Thus, they act as 'miniature reservoirs'. They undergo volume transition in response to physical and chemical stimuli depending on the environmental conditions (Ahmed, 2015). The hydrogel gradually releases up to $95 \%$ of its stored water when its surroundings begin to dry out. But, when comes in contact with water again, it gets replenished. This process can last up to 2-5 years, by which time biodegradable hydrogel decomposes to $\mathrm{CO}_{2}$, water and ammonia and potassium ions, without any residue, thus, environment friendly (Trenkel, 1997). Further, they acts as soil conditioners and improve the physical properties of soils viz., porosity, bulk density, water holding capacity, soil permeability and infiltration rate. They improve the crop growth by increasing water holding capacity in soil and delays the wilting point in drought stress (Boatright et al., 1997). Many authors have reported positive (Rehman et al., 2011; Singh, 2012; Langaroodi et al., 2013) and negative (Mandal, 2015) results in terms of moisture conservation and yield improvement in several crops with an exception of economic feasibility. However, its' usage is not being explored so far in rainfed castor. Hence, we have evaluated agronomically and economically the impact of hydrogel in rainfed castor on Alfisols.

\section{Materials and Methods}

\section{Experiment location and details}

A field experiment was conducted at Regional Agricultural Research Station, Professor Jayashankar Telangana State Agricultural University, Palem, Telangana state, India during kharif season of 2016 and 2017 under rainfed conditions to find out the effect of hydrogel addition on soil moisture retentivity and economic yield of castor. The soil of experimental site was Alfisol with a $\mathrm{pH}$ of 7.1, EC of $0.022 \mathrm{dSm}^{-1}$, low in available nitrogen $\left(176 \mathrm{~kg} \mathrm{~N} \mathrm{ha}{ }^{-1}\right)$, medium in available phosphorus (40.46 $\mathrm{kg} \mathrm{P}_{2} \mathrm{O}_{5} \mathrm{ha}^{-1}$ ) and high in 
potassium (423 $\mathrm{kg} \mathrm{K}_{2} \mathrm{O} \mathrm{ha}^{-1}$ ). There were four treatments viz., Control (No hydrogel), $2.5 \mathrm{~kg}$ $\mathrm{ha}^{-1}$ hydrogel, $5.0 \mathrm{~kg} \mathrm{ha}^{-1}$ hydrogel and $7.5 \mathrm{~kg}$ $\mathrm{ha}^{-1}$ hydrogel, each replicated five times. The experiment was conducted in a randomized complete block design (RCBD). Seeds were dibbled at $120 \mathrm{~cm} x 45 \mathrm{~cm}$ spacing on 13-072016 and 08-07-2017 during 2016 and 2017, respectively. Hydrogel with the trade name Vaaridhar G-1 Pusa hydrogel obtained from Vishwa Hydrogel Pvt. Ltd., Gurgaon, Haryana, India was used for experimentation purpose. One gram hydrogel had on an average 560 granules. It was mixed with FYM in 1:10 ratio and applied by pocketing method below seed zone. All the four treatments received an uniform recommended dose of fertilizers i.e., $80 \mathrm{~kg} \mathrm{~N}, 40 \mathrm{~kg} \mathrm{P}_{2} \mathrm{O}_{5}$ and $30 \mathrm{~kg}$ $\mathrm{K}_{2} \mathrm{O} \mathrm{ha}^{-1}$ through urea, diammonium phosphate and muriate of potash. Half the dose of nitrogen, entire dose of phosphorus and potash was applied as basal at 15 days after sowing (DAS). Rest of the nitrogen dose was applied in three equal splits at 30,60 and 90 DAS by pocketing method. Need based plant protection measures were taken up against semilooper, spodoptera and Botryotinia gray mold. A gross plot size of $7.2 \mathrm{mx} 6.75 \mathrm{~m}$ and a net plot size of $4.8 \mathrm{mx} 4.95 \mathrm{~m}$ was maintained. The crop was kept weed free by spraying a pre-emergence herbicide pendimethalin @ $1.0 \mathrm{~kg}$ a.i ha ${ }^{-1}$ followed by two times intercultivation with tractor drawn blade.

The growth and yield traits were recorded at the time of harvesting of primary raceme at 120 DAS on randomly tagged five plants with in the net plot. A total of three pickings were done during November and December months. Seed yield from all the three pickings was pooled for arriving at final seed yield and the same was expressed as tonnes per hectare $(t$ $\left.\mathrm{ha}^{-1}\right)$.

The oil content of seed samples of castor was determined using NMR facility at ICAR-
Indian Institute of Oilseeds Research, Hyderabad, India. The oil yield was computed by multiplying the oil content with seed yield of castor.

\section{Soil moisture studies}

Soil samples were drawn with the help of screw auger at fortnightly interval upto 150 DAS and per cent soil moisture was estimated by using gravimetric method by using the following formula.

Per cent soil moisture by gravimetric method:

(Fresh weight - Dry weight/Dry weight)*100

\section{Chemical analysis}

Initial and post harvest soil available N, P, and $\mathrm{K}$ were estimated using alkaline permanganate method (Subbiah and Asija, 1956), Olsens' method (Olsen et al., 1954) and ammonium acetate method (Jackson, 1973), respectively. $\mathrm{N}, \mathrm{P}$ and $\mathrm{K}$ content in the straw and seed samples were determined by micro-kjeldhal method (Piper, 1966), vanadomolybdo phosphoric yellow color method and flame photometer method (Jackson, 1973), respectively. Nutrient uptake by seed or stalk was calculated as a function of nutrient content $(\%)$ and seed or stalk yield.

\section{Climate data}

An amount of $482.4 \mathrm{~mm}$ rainfall was received in 27 rainy days in 2016 and $418.8 \mathrm{~mm}$ in 34 rainy days in 2017 during $28^{\text {th }}$ to $52^{\text {nd }}$ standard meteorological week (SMW). The rainfall pattern depicted in figure 1 indicated that, in 2016, rainfall received during 28 and 29 SMWs coinciding with germination phase, was excess than normal, while, it was scanty during 32-34 SMWs coinciding with vegetative phase. Excess rainfall was received during $35-39^{\text {th }}$ SMWs barring $36^{\text {th }}$ week which was scanty. This period coincided with 
primary spike development/secondary spike initiation phase. Rainfall received from $40^{\text {th }}$ week onwards was scanty and it coincided with primary spike maturity and secondary development phases.

During 2017, rainfall received during 28 and 29 weeks coinciding with germination phase, was excess as compared to that of normal (Fig.2.). On the other hand, it was deficit to scanty during 30-32 weeks coinciding with vegetative phase; scanty during 34-38 weeks with an exception of $35^{\text {th }}$ week where in it was excess, coinciding with active vegetative phase and primary spike development/secondary spike initiation phases. Rainfall received during 39 and $41^{\text {st }}$ week was excess coinciding with primary spike maturity and secondary development phases. Thereafter, it was scanty for the rest of crop period.

\section{Statistical analysis}

The data was analyzed statistically in a randomised block design using OPSTAT. The significance of the treatment effect was determined using the F-test. Least significant differences were calculated at the $5 \%$ probability level to determine the significance of the difference between two treatments (Gomez and Gomez, 1984). As the year was statistically significant, the data was presented separately for the two years.

\section{Results and Discussion}

The data presented in Table 1 and Table 2 indicated that growth and yield traits and seed yield of castor were higher in 2017 (2070 to $2171 \mathrm{~kg} \mathrm{ha}^{-1}$ ) than that of 2016 (1055 to 1145 $\left.\mathrm{kg} \mathrm{ha}{ }^{-1}\right)$. The probable reasons were, though less amount of rainfall was received in 2017 (418.8 $\mathrm{mm}$ in 34 rainy days) as compared to that of 2016 (482.4 $\mathrm{mm}$ in 27 rainy days), its' distribution was better in 2017. High intensity rainfall of $117 \mathrm{~mm}$ received on $30-8-16\left(35^{\text {th }}\right.$ week) has helped to get better yield from primary raceme, but scanty rainfall from $40^{\text {th }}$ week onwards affected the yield from other racemes in 2016. On the otherhand, during 2017, though primary raceme yield was affected due to scanty rainfall between 34 and 38 weeks, good amount of rainfall received during $42^{\text {nd }}$ week (53.8 $\mathrm{mm}$ on 16-10-17) might have helped to build up soil moisture (Fig. 2 and 3) thus plants might have extracted moisture from soil and produce better yield from different order racemes.

Irrespective of year of study, plant height, total and effective raceme length and 100 seed weight of castor plants were numerically higher when hydrogel was not applied as compared to that of hydrogel applied crop (Table 1 and 2). However, statistically no significant differences were observed among all four treatments. Increase in dose from 2.5 $\mathrm{kg}$ to $7.5 \mathrm{~kg} \mathrm{ha}^{-1}$ hydrogel also couldn't help to improve significantly the seed yield of castor. Similar is the trend with oil content and oil yield during both the years. Agronomic efficiency of hydrogel application indicated that response of castor in terms of seed yield reduced due to hydrogel application in both the years. Further, N, P and K uptake by castor plants also didn't differ significantly due to hydrogel application during first year, however, 2.5 and $7.5 \mathrm{~kg} \mathrm{ha}^{-1}$ hydrogel applied crop removed higher $\mathrm{N}$ than that of control and $5.0 \mathrm{~kg} \mathrm{ha}^{-1}$ during second year. Similarly, $\mathrm{P}$ removal by castor crop was significantly more in all hydrogel applied treatments than that of control.

The research reports were both positive and negative with regard to effect of hydrogel application. Though seed germination of wheat and barley was not affected but seedling growth was improved due to gel amendment. It caused a delay by 4-5 days in wilting of seedlings grown compared with control conditions. 
Table.1 Effect of hydrogel on growth and yield traits of castor under rainfed conditions (Kharif 2016)

\begin{tabular}{|c|c|c|c|c|c|c|c|c|c|c|c|c|c|c|c|}
\hline Treatment & $\begin{array}{l}\text { Plant } \\
\text { height } \\
(\mathrm{cm})\end{array}$ & $\begin{array}{c}\text { No. of } \\
\text { branches } \\
\text { plant }^{-1}\end{array}$ & $\begin{array}{l}\text { No. of } \\
\text { nodes } \\
\text { plant }^{-1}\end{array}$ & $\begin{array}{c}\text { No. of } \\
\text { racemes } \\
\text { plant }^{-1}\end{array}$ & $\begin{array}{l}\text { No. of } \\
\text { effective } \\
\text { racemes }^{-1} \text { plant }^{-1}\end{array}$ & $\begin{array}{l}\text { Total } \\
\text { primary } \\
\text { racemes } \\
\text { length } \\
(\mathrm{cm})\end{array}$ & $\begin{array}{l}\text { Eff. } \\
\text { primary } \\
\text { raceme } \\
\text { length } \\
(\mathrm{cm})\end{array}$ & $\begin{array}{c}100 \text { seed } \\
\text { weight } \\
(\mathrm{g})\end{array}$ & $\begin{array}{c}\text { Seed } \\
\text { yield } \\
(\mathrm{kg} \\
\left.\mathrm{ha}^{-1}\right)\end{array}$ & $\begin{array}{l}\text { Agronomic } \\
\text { efficiency } \\
\text { (kg yield } \mathrm{kg}^{-1} \\
\text { hydrogel } \\
\text { applied) }\end{array}$ & $\begin{array}{c}\text { Oil } \\
\text { content } \\
(\%)\end{array}$ & $\begin{array}{c}\text { Oil } \\
\text { yield } \\
(\mathrm{kg} \\
\left.\mathrm{ha}^{-1}\right)\end{array}$ & $\begin{array}{c}\mathrm{N} \\
\text { uptake } \\
(\mathrm{kg} \\
\left.\mathrm{ha}^{-1}\right)\end{array}$ & $\begin{array}{c}\mathrm{P} \\
\text { uptake } \\
(\mathrm{kg} \\
\left.\mathrm{ha}^{-1}\right)\end{array}$ & $\begin{array}{c}\mathrm{K} \\
\text { uptake } \\
(\mathrm{kg} \\
\left.\mathrm{ha}^{-1}\right)\end{array}$ \\
\hline $\begin{array}{c}\text { Control (No } \\
\text { hydrogel) }\end{array}$ & 43.5 & 2.08 & 12.04 & 3.2 & 1.88 & 31.1 & 23.5 & 30.2 & 1130 & - & 49.6 & 560 & 85.3 & 10.5 & 16.5 \\
\hline $\begin{array}{c}\text { Hydrogel @ } \\
2.5 \mathrm{~kg} \mathrm{ha}^{-1}\end{array}$ & 41.2 & 2.08 & 10.92 & 3.2 & 1.56 & 30.0 & 19.4 & 28.4 & 1145 & 458 & 49.3 & 564 & 87.7 & 15.4 & 21.9 \\
\hline $\begin{array}{c}\text { Hydrogel @ } \\
5.0 \text { kg ha }^{-1}\end{array}$ & 40.4 & 2.20 & 10.96 & 3.4 & 1.60 & 29.5 & 21.9 & 28.7 & 1122 & 224 & 50.5 & 567 & 87.0 & 16.0 & 22.1 \\
\hline $\begin{array}{c}\text { Hydrogel @ } \\
7.5 \mathrm{~kg} \mathrm{ha}^{-1}\end{array}$ & 38.6 & 2.24 & 11.60 & 3.60 & 1.73 & 30.2 & 22.5 & 31.3 & 1055 & 141 & 49.5 & 524 & 81.3 & 14.3 & 21.3 \\
\hline SEm \pm & 3.30 & 0.16 & 0.61 & 0.23 & 0.16 & 2.1 & 1.5 & 2.91 & 101 & & 0.24 & 52 & 7.8 & 1.97 & 3.2 \\
\hline CD (0.05) & NS & NS & NS & NS & NS & $\mathrm{NS}$ & NS & NS & NS & & 0.73 & 158 & $\mathrm{NS}$ & NS & $\mathrm{NS}$ \\
\hline CV (\%) & 18.2 & 16.5 & 12.02 & 15.4 & 20.4 & 15.2 & 15.4 & 2.5 & 20.3 & & 1.07 & 21 & 20.5 & 31.3 & 34.9 \\
\hline
\end{tabular}

Table.2 Effect of hydrogel on growth and yield traits of castor under rainfed conditions (Kharif 2017)

\begin{tabular}{|c|c|c|c|c|c|c|c|c|c|c|c|c|c|c|c|}
\hline Treatments & $\begin{array}{l}\text { Plant } \\
\text { height } \\
(\mathrm{cm})\end{array}$ & $\begin{array}{l}\text { No. of } \\
\text { branches } \\
\text { plant }^{-1}\end{array}$ & $\begin{array}{l}\text { No. of } \\
\text { nodes } \\
\text { plant }^{-1}\end{array}$ & $\begin{array}{l}\text { No. of } \\
\text { racemes } \\
\text { plant }^{-1}\end{array}$ & $\begin{array}{l}\text { No. of } \\
\text { effective } \\
\text { racemes } \\
\text { plant }^{-1}\end{array}$ & $\begin{array}{l}\text { Total } \\
\text { primary } \\
\text { racemes } \\
\text { length } \\
(\mathrm{cm})\end{array}$ & $\begin{array}{l}\text { Eff. primary } \\
\text { raceme } \\
\text { length }(\mathrm{cm})\end{array}$ & $\begin{array}{c}100 \text { seed } \\
\text { weight } \\
(\mathrm{g})\end{array}$ & $\begin{array}{l}\text { Seed } \\
\text { yield } \\
(\mathrm{kg} \\
\left.\mathrm{ha}^{-1}\right)\end{array}$ & $\begin{array}{l}\text { Agronomic } \\
\text { efficiency } \\
\text { (kg yield } \\
\mathrm{kg}^{-1} \\
\text { hydrogel } \\
\text { applied) }\end{array}$ & $\begin{array}{c}\text { Oil } \\
\text { content } \\
(\%)\end{array}$ & $\begin{array}{c}\text { Oil } \\
\text { yield } \\
(\mathrm{kg} \\
\left.\mathrm{ha}^{-1}\right)\end{array}$ & $\begin{array}{c}\mathrm{N} \\
\text { uptake } \\
(\mathrm{kg} \\
\left.\mathrm{ha}^{-1}\right)\end{array}$ & $\begin{array}{c}\mathrm{P} \\
\text { uptake } \\
(\mathrm{kg} \\
\left.\mathrm{ha}^{-1}\right)\end{array}$ & $\begin{array}{c}\mathrm{K} \\
\text { uptake } \\
(\mathrm{kg} \\
\left.\mathrm{ha}^{-1}\right)\end{array}$ \\
\hline $\begin{array}{c}\text { Control (No } \\
\text { hydrogel) }\end{array}$ & 64.6 & 13.4 & 11.7 & 6.6 & 5.1 & 32.3 & 31.8 & 32.2 & 2141 & - & 46.41 & 993 & 107.5 & 19.7 & 30.0 \\
\hline $\begin{array}{c}\text { Hydrogel @ } \\
2.5 \mathrm{~kg} \mathrm{ha}^{-1}\end{array}$ & 59.5 & 12.7 & 11.5 & 6.6 & 4.5 & 29.7 & 27.4 & 31.6 & 2070 & 828 & 45.60 & 944 & 115.3 & 29.0 & 42.2 \\
\hline $\begin{array}{c}\text { Hydrogel @ } \\
5.0 \mathrm{~kg} \mathrm{ha}^{-1}\end{array}$ & 58.2 & 12.3 & 11.9 & 6.5 & 4.7 & 27.9 & 26.6 & 31.1 & 2171 & 434 & 45.83 & 995 & 107.9 & 30.7 & 44.1 \\
\hline $\begin{array}{c}\text { Hydrogel @ } \\
7.5 \mathrm{~kg} \mathrm{ha}^{-1}\end{array}$ & 63.1 & 13.3 & 12.1 & 6.6 & 4.7 & 32.0 & 29.4 & 31.9 & 2155 & 287 & 46.18 & 996 & 114.7 & 30.3 & 43.9 \\
\hline SEm \pm & 1.9 & 0.4 & 0.3 & 0.3 & 0.3 & 2.0 & 2.2 & 0.4 & 42 & & 0.49 & 23 & 2.3 & 2.4 & 3.8 \\
\hline CD (0.05) & NS & NS & NS & NS & NS & NS & NS & NS & NS & & NS & NS & 6.9 & 7.5 & NS \\
\hline CV (\%) & 7.1 & 7.2 & 6.5 & 9.8 & 12.4 & 14.5 & 17.1 & 3.0 & 4.5 & & 2.36 & 5.2 & 14.5 & 19.6 & 21.3 \\
\hline
\end{tabular}


Table.3 Effect of hydrogel application on the economics of rainfed castor cultivation

\begin{tabular}{|c|c|c|c|c|c|c|c|c|c|c|c|c|c|c|}
\hline \multirow[t]{2}{*}{ Treatment } & \multicolumn{4}{|c|}{2016} & \multicolumn{4}{|c|}{2017} & \multicolumn{6}{|c|}{ Mean of two years } \\
\hline & $\begin{array}{c}\text { COC } \\
\left(\operatorname{Rs~ha}^{-1}\right)\end{array}$ & $\begin{array}{c}\text { Gross } \\
\text { returns } \\
\left(\mathrm{Rs} \mathrm{ha}^{-1}\right)\end{array}$ & $\begin{array}{c}\text { Net } \\
\text { returns } \\
\left(\operatorname{Rs~ha}^{-1}\right)\end{array}$ & $\begin{array}{l}\mathrm{B}: \mathrm{C} \\
\text { ratio }\end{array}$ & $\begin{array}{c}\text { COC } \\
\left(\mathrm{Rs} \mathrm{ha}^{-1}\right)\end{array}$ & $\begin{array}{c}\text { Gross } \\
\text { returns } \\
\left(\mathrm{Rs} \mathrm{ha}^{-1}\right)\end{array}$ & $\begin{array}{c}\text { Net } \\
\text { returns } \\
\left(\operatorname{Rs~ha}^{-1}\right)\end{array}$ & $\begin{array}{l}\mathrm{B}: \mathrm{C} \\
\text { ratio }\end{array}$ & $\begin{array}{c}\text { COC } \\
\left(\operatorname{Rs~ha}^{-1}\right)\end{array}$ & $\begin{array}{c}\text { Gross } \\
\text { returns } \\
\left(\operatorname{Rs~ha}^{-1}\right)\end{array}$ & $\begin{array}{c}\text { Net } \\
\text { returns } \\
\left(\operatorname{Rs~ha}^{-1}\right)\end{array}$ & $\begin{array}{l}\mathrm{B}: \mathrm{C} \\
\text { ratio }\end{array}$ & $\begin{array}{l}\text { Additional } \\
\text { expenditure } \\
\left(\operatorname{Rs~ha}^{-1}\right)\end{array}$ & $\begin{array}{l}\text { Additional } \\
\text { net returns } \\
\left(\text { Rs ha }{ }^{-1}\right) \\
\text { over control }\end{array}$ \\
\hline $\begin{array}{c}\text { Control (No } \\
\text { hydrogel) }\end{array}$ & 28750 & 39551 & 10801 & 1.38 & 30000 & 81366 & 51366 & 2.71 & 29375 & 60459 & 31084 & 2.04 & - & 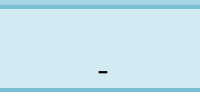 \\
\hline $\begin{array}{c}\text { Hydrogel @ } \\
2.5 \mathrm{~kg} \mathrm{ha}^{-1}\end{array}$ & 32500 & 40061 & 7811 & 1.24 & 33500 & 78668 & 45168 & 2.35 & 32875 & 59365 & 26490 & 1.80 & 3500 & -4594 \\
\hline $\begin{array}{c}\text { Hydrogel @ } \\
5.0 \mathrm{~kg} \mathrm{ha}^{-1}\end{array}$ & 35750 & 39278 & 3528 & 1.10 & 37000 & 82509 & 45509 & 2.23 & 36375 & 60894 & 24519 & 1.66 & 7000 & -6565 \\
\hline $\begin{array}{c}\text { Hydrogel @ } \\
7.5 \mathrm{~kg} \mathrm{ha}^{-1}\end{array}$ & 39250 & 36930 & -2320 & 0.94 & 40500 & 81894 & 41394 & 2.02 & 39875 & 59412 & 19537 & 1.48 & 10500 & -11547 \\
\hline
\end{tabular}

COC: Cost of cultivation

Market rate of hydrogel: Rs. $1400 \mathrm{~kg}^{-1}$

Market rate of castor seeds: Rs. $35 \mathrm{~kg}^{-1}$ in 2016 and $38 \mathrm{~kg}^{-1}$ in 2017

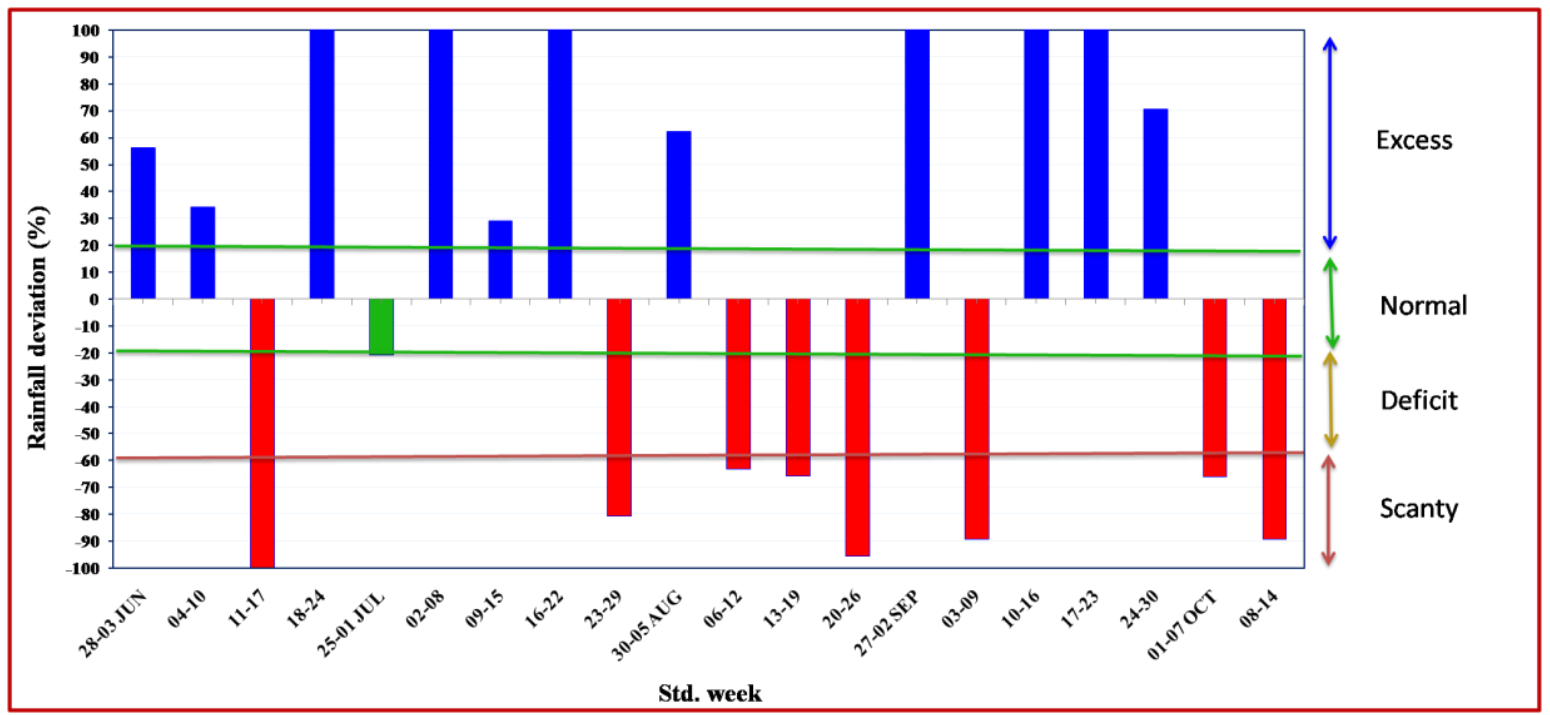

Fig.1 Weekly rainfall deviation (\%) during 2016 at Palem 


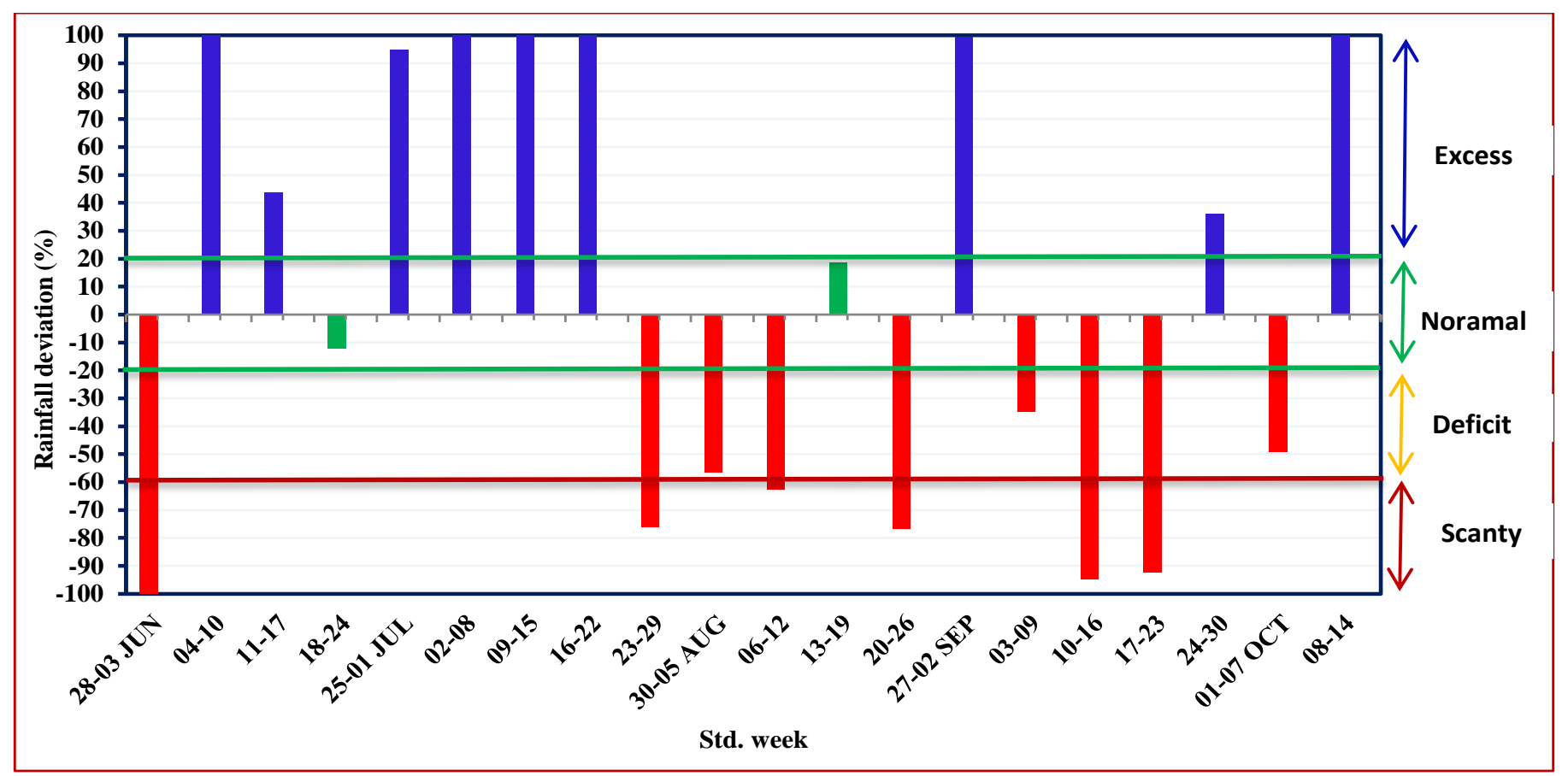

Fig.2 Weekly rainfall deviation (\%) during 2017 at Palem 
Int.J.Curr.Microbiol.App.Sci (2018) 7(7): 3206-3217

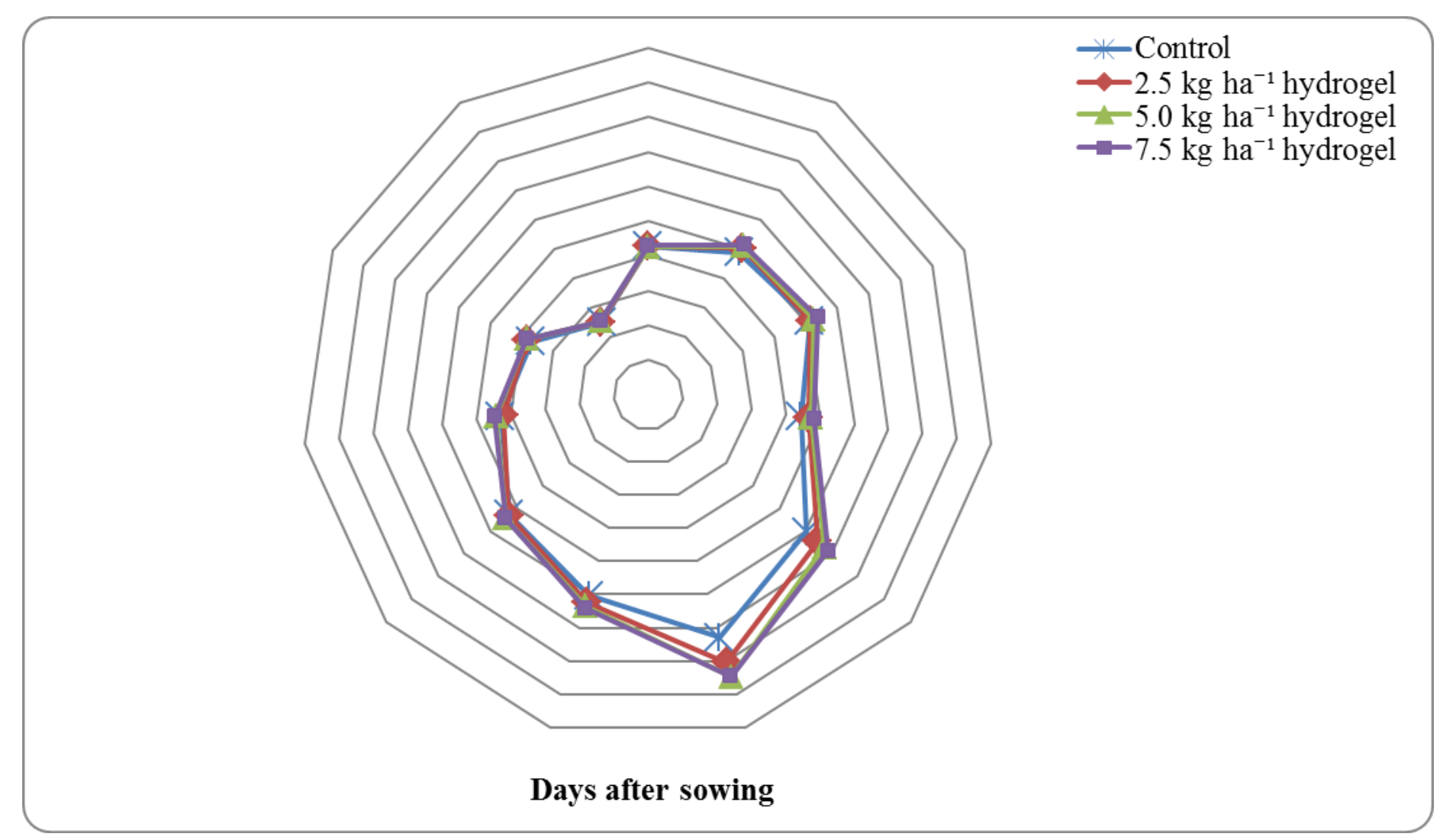

Fig.3 Changes in per cent soil moisture due to hydrogel application in rainfed castor (kharif 2016) 
Int.J.Curr.Microbiol.App.Sci (2018) 7(7): 3206-3217

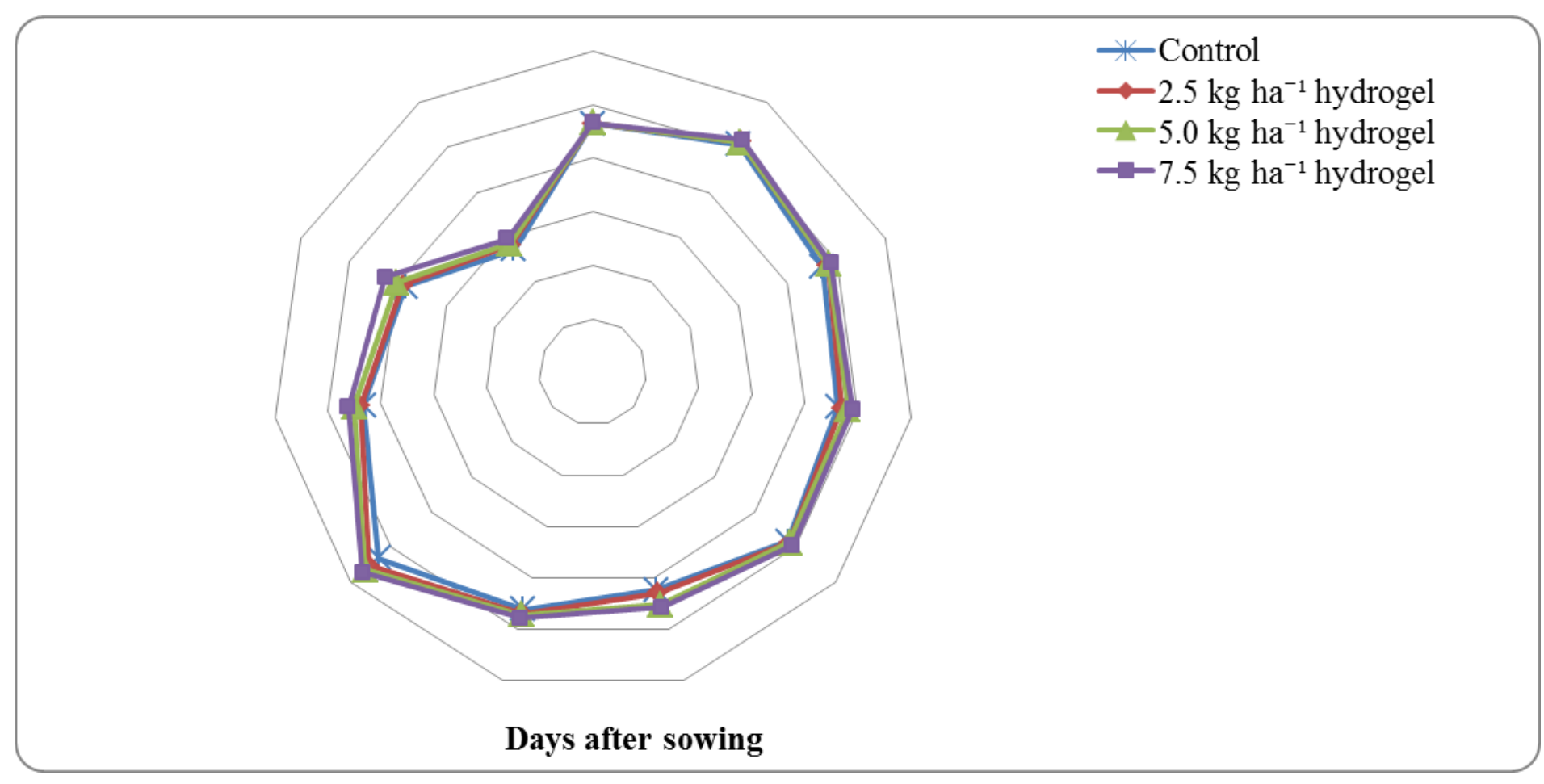

Fig.4 Changes in per cent soil moisture due to hydrogel application in rainfed castor (kharif 2017) 
An increase in water holding capacity due to hydrogel significantly reduced the irrigation requirement of many plants (Taylor and Halfacre, 1986). Borivoj et al. (2006) reported only $8.48 \%$ yield improvement with the application of $5 \mathrm{~kg} \mathrm{ha}^{-1}$ of hydrogel in clay loam soil with $100 \%$ recommended dose of fertilizers in wheat over control. According to Singh (2012), coating of pearl millet seed with 10 and $20 \mathrm{~g}$ of hydrogel $\mathrm{kg}^{-1}$ of seed resulted in the production of significantly higher effective tillers, ear length, test weight, grain and stover yield compared to control and water soaking treatment. Application of $200 \mathrm{~kg} \mathrm{ha}^{-1}$ of hydrogel in peanut resulted in significant improvement in growth and yield traits in sandy soil with hot and arid climate (Langaroodi et al., 2013). The current experiments' result is tune with that of Mandal (2015) who reported that hydrogel was not effective for groundnut and pigeonpea crops during kharif season but positive effect on tomato when it was tested at higher rates of $25-100 \mathrm{~kg} \mathrm{ha}^{-1}$. Similarly, Rohit Kumar (2015) reported significantly higher grain yield of maize at $\geq 10 \mathrm{~kg} \mathrm{ha}^{-1}$ hydrogel.

According to Akhter et al., (2004), addition of $0.1,0.2$ and $0.3 \%$ hydrogel increased the moisture retention at field capacity linearly $(r=0.988)$ and thus the amount of plant available water significant in both sandy loam and loam soils compared to the untreated soils. In our experiment, no doubt, hydrogel addition has slightly improved the soil moisture content as compared to that of control (fig. 3 and 4), however, castor plants couldn't utilize the same due to its' deep rooted nature and long duration thus it was not reflected in yield improvement. Our results are in agreement with that of Ingram and Yeager (1987) and Wang (1987) who reported that despite various beneficial effects of hydrogel addition, studies have shown little or no benefit with hydrogel addition.
The information on economic evaluation of hydrogel application in various crops across the globe is meagre. In the current study, the average of two years data (Table 3) showed that castor crop grown without hydrogel addition has accrued higher net returns (Rs. $31084 \mathrm{ha}^{-1}$ ) and B:C ratio (2.04). Further, addition of hydrogel has brought down the net returns and B:C ratio to Rs. $26490 \mathrm{ha}^{-1}, 1.80$ (2.5 kg ha ${ }^{-1}$ hydrogel); Rs. $24519 \mathrm{ha}^{-1}, 1.66$ (5.0 $\mathrm{kg} \mathrm{ha}^{-1}$ hydrogel) and Rs. $19537 \mathrm{ha}^{-1}$, 1.48 (7.5 kg ha ${ }^{-1}$ hydrogel) drastically. It was mainly due to no significant improvement in seed yield and also higher cost of hydrogel (Rs. $1400 \mathrm{~kg}^{-1}$ ). A minimum increase in seed yield by $200 \mathrm{~kg} \mathrm{ha}^{-1}$ is required to compensate the increased cost due to hydrogel addition. Further, an increase in seed yield by $400-500$ $\mathrm{kg} \mathrm{ha}{ }^{-1}$ is required to achieve higher net returns and B:C ratio. Such results were also reported by Islam et al., (2011) who concluded that optimum dose of super absorbent polymer for maize cultivation was $30 \mathrm{kgha}^{-1}$ and lower (10-20 kg ha ${ }^{-1}$ ) or higher $\left(\geq 40 \mathrm{~kg} \mathrm{ha}^{-1}\right)$ would neither be sufficient nor economical. Furthermore, Rohith Kumar (2015) concluded that higher $\mathrm{B}: \mathrm{C}$ ratio of 2.15 was obtained without hydrogel application as compared to that of hydrogel applied @ $10 \mathrm{~kg} \mathrm{ha}^{-1}$ (1.86), $15 \mathrm{~kg} \mathrm{ha}^{-1}$ (1.72), $20 \mathrm{~kg} \mathrm{ha}^{-1}$ (1.52), $25 \mathrm{~kg} \mathrm{ha}^{-1}$ (1.36) and $30 \mathrm{~kg}$ $\mathrm{ha}^{-1}(1.24)$ in rabi maize in Bihar, India.

In conclusions, our results clearly indicated that hydrogel application failed to enhance the seed yield of castor, though it helped to slightly improve the soil moisture content. Further, addition of hydrogel has reduced the net returns and benefit per rupee invested. Though various authors have reported positive reports on yield improvement across the globe, its economics has received less attention. In view of higher cost, its' usage can be promoted only in high value crops which are grown under protected structures like shadenets or green houses or polyhouses. 


\section{References}

Abdelfattah, M.A. 2013. Pedogenesis, land management and soil classification in hyper-arid environments: results and implications from a case study in the United Arab Emirates.Soil Use and Manage., 29: 279-294.

Ahmed, E.M. 2015. Hydrogel: Preparation, characterization, and applications: A review. J. Adv.Res., 6: 105-121.

Akhter, J., Mahmood, K., Malik, K.A., Mardan, A., Ahmad, M., and Iqbal, M.M. 2004. Effects of hydrogel amendment on water storage of sandy loam and loam soils and seedling growth of barley, wheat and chickpea. Pl. Soil and Env., 50(10): 463-469.

Boatright, J.L., Balint, D.E., Mackay, W.A., and Zajicek, J.M. 1997. Incorporation of a hydrophilic polymer into annual landscape beds. J. Env. Hort., 15: 37 40.

Borivoj, S., Rak, L., and Bubenikova, I. 2006. The effect of hydroabsorbent on selected soil biological and biochemical characteristics and its possible use in revitalization. Ecologia., 25(4): 422-429.

Dehkordi, D.K. 2016. The effects of superabsorbent polymers on soils and plants. Pertanika. J. Trop. Agric. Sci., 39(3): 267-298.

Falkenmark, M., and Rockström, J. 2004. Balancing water for humans and nature: The new approach in Ecohydrology. Earthscan, London, UK.

Gomez, K.A., and Gomez, A.A. 1984. Statistical procedures for Agricultural Research. Edn. 2, John Wiley and Sons, New York.

IIOR, 2018. Director's report. Annual Group Meeting of Oilseeds, May 17-19, 2018. Indian Institute of Oilseeds Research, Rajendranagar, Hyderabad
500 030, Telangana, India. p.34.

Ingram, D.L., and Yeager, T.H. 1987. Effect of irrigation frequency and a waterabsorbing polymer amendment on Ligustrum growth and moisture retention by a container medium. $J$. Env. Hort., 5: 19-21.

Islam, M.R., Hu, Y., Mao, S., Jia, P., Eneji, A.E., and Xue, X. 2011. Effects of water saving superabsorbent polymer on antioxidant enzyme activities and lipid peroxidation in corn (Zea mays L.) under drought stress. J. Sci. Food and Agric., 91: 813-819.

Jackson, M.L. 1973. Soil chemical analysis. Prentice hall of India Pvt ltd., New Delhi.

Kalhapure, A., Rajeew Kumar, Singh, V.P., and Pandey, D.S. 2016. Hydrogels: a boon for increasing agricultural productivity in water-stressed environment. Cur. Sci., 111(11): 1773-1779.

Krishna, A. and Ramanjaneyulu, A.V. 2012. Impact of land configuration, life saving irrigation and intercropping on yield and economics of major rainfed crops in Southern Telangana Zone of Andhra Pradesh, India. Int. J. Bio-res. Stress Manage., 3(3): 317-323.

Olsen, S.R., Cole, C.W., Watanabe, F.S. and Dean, L.A. 1954. Estimation of available $\mathrm{P}$ in soils by extraction with sodium bicarbonate. USDA circular No. 439.

Piper, C.S. 1966. Soil and plant analysis. Academic Press, New York. 368.

Rehman, A., Ahmad, R., and Safdar, M. 2011. Effect of hydrogel on the performance of aerobic rice sown under different techniques. Pl. Soil and Env., 57(7): 321-325.

Ramanjaneyulu, A.V., Anudradha, G., Venkata Ramana, M., Vishnu Vardhan Reddy, A., and Madana Gopal, N. 2017. Multifarious Uses of Castor 
(Ricinus communis L.). Int. J. Econ. Pl., 4(4): 170-176.

Ramanjaneyulu, A.V, Neelima, T.L., Nagesh Kumar, M.V., and Sreenivas, A. 2015. Drought mitigation in rainfed castor through farm pond technology. In: Souvenir and Extended summaries of National Seminar on Strategic interventions to enhance oilseeds production in India, Feb 19-21, 2015 at DRMR, Bharatpur, Rajasthan, India. 163-164

Rohith Kumar, 2015. Evaluation of hydrogel on the performance of rabi maize (Zea mays L.). M.Sc. thesis submitted to the Department of Agronomy, Bihar Agricultural University, Sabour, Bhagalpur, Bihar, India.

Singh, H. 2012. Effect of hydrogel on growth, yield and water use efficiency in pearl millet (Pennisetum glaucum) production. Forage Res., 38(1), 2728.

Subbaiah, B.V., and Asija, G.L. 1956. A rapid procedure for the determination of available nitrogen in soils. Cur. Sci., 25: 259-260.

Taylor, K.C., and Halfacre, R.G. 1986. The effect of hydrophilic polymer on media water retention and nutrient availability to Ligustrum lucidum. Hort. Sci., 21: 1159-1161.

Wang, Y.T. 1987. Driving your soil to drink. Greenhouse Management., 6: 115120.

Langaroodi, N.B.S., Ashouri, M., Dorodian, H.R., and Azarpour, E. 2013. Study effects of super absorbent application, saline water and irrigation management on yield and yield components of peanut (Arachis hypogaea L.). Ann. Biolog. Res., 4(1): 160-169.

Mandal, U.K., Sharma, K.L., Venkanna, K., Korwar, G.R., Reddy, K.S., Pushpanjali, Reddy, N.N., Venkatesh, G., Masane, R.N., and Yadaiah, P. 2015. Evaluating hydrogel application on soil water availability and crop productivity in semi arid tropical red soil. Ind. J. Dryland Agric. Res. Dev., 30(2): 1-10.

Trenkel, M.E. 1997. Controlled release and stabilized fertilizers in Agriculture. International Fertilizer Industry Association, Paris, France.

\section{How to cite this article:}

Ramanjaneyulu, A. Madhavi, G. Anuradha, M. Venkata Ramana, G. Suresh, B. Balaji Naik and Seshu, G. 2018. Agronomic and Economic Evaluation of Hydrogel Application in Rainfed Castor Grown on Alfisols. Int.J.Curr.Microbiol.App.Sci. 7(07): 3206-3217. doi: https://doi.org/10.20546/ijcmas.2018.707.374 